\title{
Influence of nitrogen enrichment on size-fractionated in vitro carboxylase activities of phytoplankton from Thau Lagoon (Coastal Mediterranean Lagoon, France)
}

\author{
Eric Fouilland ${ }^{a, \star}$, Chantal Descolas-Gros ${ }^{a}$, Yves Collos ${ }^{a}$, André Vaquer ${ }^{a}$, Philippe Souchu ${ }^{b}$, Anne \\ Gasc $^{b}$, Bertrand Bibent ${ }^{a}$ and Virginie Pons ${ }^{a}$
}

\author{
a Laboratoire d'Hydrobiologie Marine et Continentale, UMR 5556 CNRS, Université Montpellier II, \\ Case 093, 34095, Montpellier Cedex 05, France \\ ${ }^{\mathrm{b}}$ Laboratoire Ecologie, station IFREMER, 1 rue Jean Vilar, 34200 Sète, France
}

\footnotetext{
*: Corresponding author : Present address: The Scottish Association For Marine Science (SAMS), Dunstaffnage Marine Laboratory, Dunbeg, , Oban, Argyll, PA37 1QA, , UK. Tel.: +44-1631-559323; fax: +44-1631-559001; email: erfo@dml.ac.uk
}

\begin{abstract}
:
The influence of dissolved inorganic and organic nitrogen (DIN and DON) enrichments on pools of enzymes responsible for $\mathrm{CO}_{2}$ fixation by the Calvin-Benson (Rubisco) and $\beta$-carboxylation pathways ( $\beta$-carboxylases) were studied in a natural plankton assemblage. The plankton community from a coastal Mediterranean lagoon were incubated in situ for $24 \mathrm{~h}$ with initially ammonium, nitrate and DON (taurine) enrichments and compared to a control without any enrichment. An increase of small picophytoplankton and diatom biomass was observed in the enriched inorganic nitrogen treatments 7$10 \mathrm{~h}$ after the initial enrichment. Phytoplankton biomass decreased in the control and under taurine enrichment suggesting an inorganic nitrogen limitation of phytoplankton growth. Nevertheless, the ratio of particulate carbon (C) versus chlorophyll a concentrations decreased throughout the experiment, pointing out the increasing importance of the autotroph community in all the carboys. The pool of Rubisco enzyme per biomass generally decreased in all the incubation carboys. In contrast, an increase in the pool of $\beta$-carboxylase enzymes normalised to the particulate carbon, chlorophyll and cell concentrations was observed at the end of the experiment under inorganic $\mathrm{N}$-deficient conditions, in the control and with the addition of taurine. Under these latter conditions, the anaplerotic carbon fixation by $\beta$-carboxylation may potentially exceed photosynthetic carbon fixation by Rubisco in phytoplankton cells. A shift towards heterotrophy for natural phytoplankton cells using organic sources of nitrogen is proposed to explain the increase of the enzymatic pool of the $\beta$-carboxylation pathway.
\end{abstract}

Keywords: Carboxylase activities; Size-fractionated phytoplankton; Nitrogen enrichments; Autotrophy; Heterotrophy 


\section{Introduction}

The nature of the interaction between nutrient assimilation and photosynthetic carbon fixation is of major importance in understanding phytoplankton growth in fluctuating environments. The metabolic pathways of carbon (C) and nitrogen (N) are linked because they must share organic C and energy. They are supplied directly from photosynthetic electron transport and $\mathrm{CO}_{2}$ fixation, or from respiration of fixed $\mathrm{C}$ via glycolysis, the TCA cycle and mitochondrial electron transport chain (Turpin, 1991; Huppe and Turpin, 1994). Modifications of photosynthesis due to variations in $\mathrm{N}$ supply have been largely ascribed to changes in the content or specific activity of the primary $\mathrm{CO}_{2}$ fixing enzyme Rubisco ( Osborne and Geider, 1986; references therein). Phytoplankton fix dissolved inorganic carbon via $\beta$-carboxylation, to replenish intermediates in the tricarboxylic acid cycle and the replacements, or anaplerotic carboxylations, to provide essential compounds for phytoplankton growth that cannot be produced from the Calvin-Benson cycle (Falkowski and Raven, 1997). This pathway leads to protein synthesis, a process using phosphenolpyruvate carboxylase (PEPC), phosphoenolpyruvate carboxykinase (PECK) or pyruvate carboxylase (PYRC) influenced by ammonium availability among others factors (Mortain-Bertrand et al., 1988). The $\beta$ carboxylation pathway is mainly driven by phosphoenolpyruvate (PEP) which originates from intermediates of Calvin-Benson cycle or, in darkness, from polysaccharides (Appleby et al., 1980, Mortain-Bertrand et al., 1987a, b).

The nature of $\mathrm{N}$ source has been demonstrated to affect the phytoplankton physiology (Levasseur et al., 1993; Fidalgo et al., 1995) such as the C fixation pathway. It has been reported that $\mathrm{C}$ fixation in darkness (via ß-carboxylation pathway) was enhanced by addition of $\mathrm{NH}_{4}^{+}$to 
N limited phytoplankton (Morris et al., 1971, Slawyk and Collos, 1982; Elrifi and Turpin, 1986; Dodds and Priscu, 1991; Vanlerberghe et al., 1990; 1992). Under steady-state conditions, the fraction of anaplerotic carbon fixation required to sustain the flux of aspartate, glutamate and their derivatives theoretically accounts for 5\% of the fixed carbon in the organism (Falkowski and Raven, 1997; references therein). Nevertherless Guy et al. (1989), using carbon isotope discrimination, showed that transient $\mathrm{N}$ assimilation by $\mathrm{N}$-limited Selenastrum minutum causes a major shift in carbon fixation from Rubisco to PEPC at high irradiance, suggesting that PEPC accounted for 70 to $87 \%$ of carbon fixation.

Though the role of $\beta$-carboxylation in the phytoplankton cells is well known as supporting the synthesis of amino acids derived from aspartate and glutamate, the origin of PEP for $\beta$ carboxylation is not clearly defined. A higher $\beta$-carboxylase activity than Rubisco activity under high irradiance, as observed by Guy et al. (1989) and Descolas-Gros and Oriol (1992) for different phytoplanktonic species in culture, suggested metabolites synthesised by other pathways in the cell or from the external medium act as carbon acceptors for $\beta$-carboxylation pathway. Thus, relative to the Rubisco activity, a high $\beta$-carboxylase activity sustained by a mixotrophic activity of the phytoplanktonic cells under $\mathrm{N}$ limiting conditions is assumed.

During the present study, the Calvin-Benson cycle and $\beta$-carboxylation pathways were both examined over 24 hours by measuring the pool of carboxylase enzymes in a natural plankton community from Thau Lagoon under different $\mathrm{N}$ conditions. The initial addition of ammonium and nitrate were compared to a control without enrichment. The heterotrophic capability of phytoplankton $\mathrm{N}$ nutrition was studied by enrichment with taurine, which is an important organic $\mathrm{N}$ compound released from oyster culture, and has been shown to be a good organic N source for phytoplankton in such ecosystems (Vincendeau, 1987). Small 
phytoplankton $(<2 \mu \mathrm{m})$ in Thau lagoon have been shown to be important in the phytoplankton biomass and in primary production, averaging about 30\% of total chlorophyll $a$ concentration and about $40 \%$ of the total annual primary production (Courties et al., 1994; Vaquer et al., 1996). This phytoplankton fraction is mainly constituted by the picoeukaryote Ostreococcus tauri with cell size less of $1 \mu \mathrm{m}$ diameter and described by Chrétiennot-Dinet et al. (1995). We have thus size-fractionated $(1 \mu \mathrm{m})$ the plankton community to study the influence of the addition of these different $\mathrm{N}$ sources on the unknown $\mathrm{CO}_{2}$ metabolism of the $<1 \mu \mathrm{m}$ cells.

\section{Material and methods}

\section{$\underline{\text { Study area }}$}

Thau lagoon (Fig. 1) is a Mediterranean coastal lagoon (France, 4324' N - $3^{\circ} 36^{\prime} \mathrm{E}$ ), shallow, (depth average of $4.5 \mathrm{~m}$ ), without tide, exposed both to continental exports and oceanic influence via the Rhône river plume (Souchu et al., 1997). Thau lagoon is one of the most important shellfish areas in Europe with an estimated standing stock of 40000 tons of oysters (Crassostrea gigas) which takes up 1/5th of the total area (7 000 ha). Salinities and temperatures vary from 24 to $38 \mathrm{PSU}$ and from 4 to $27^{\circ} \mathrm{C}$ respectively, with a $\mathrm{pH}$ of 8.2 . Little information is available regarding the physical characteristics of Thau Lagoon. Seawater turbidity is limited, with a Secchi depth ranging from $2.5 \mathrm{~m}$ to $7.7 \mathrm{~m}$ without any seasonal variation (Bacher et al., 1995). The light attenuation coefficient is about $0.35 \mathrm{~m}^{-1}$ (outside the shellfish farming areas). Hydrodynamics in the Thau Lagoon are linked with the wind regime and most of the exchanges between the lagoon and the sea occur through the Canaux de Sete (Fig. 1). The lagoon is able to 
renew $12 \%$ of its water mass within 3 days owing to wind and barometric effects (Millet, 1989). In summer, in spite of the low concentration of dissolved inorganic nitrogen (DIN), the shellfish production is generally highest in the lagoon. This suggests a high regenerated production increased by enhanced benthic nutrient fluxes (Souchu et al. 20001) and mainly based on dissolved organic matter, which represents the greatest stock of C and N (Gasc, 1997).

In Thau Lagoon, loricate ciliates such as tintinnids are abundant. Tintinnids and rotifers represented between 26 and $45 \%$ of the net collected microzooplankton biomass (Lam-Hoai et al., 1997). However, at the shellfish culture area, the occurrence of oysters and of epibiotic fauna resulted in a drastic biomass reduction of the microzooplankton. The oyster cultures contributed to the picophytoplanktonic dominance in these waters by the preferential grazing of the larger phytoplankton and zooplankton (Le Gall et al., 1997; Dupuy et al., 2000). From grazing experiments, Dupuy et al. (2000) demonstrated that small picophytoplankton were not retained by the oysters gills. Nevertheless, the picoeukaryote community constituted the most abundant primary food resource for hetero-/mixotrophic flagellates, dinoflagellates and ciliates. The whole daily picophytoplankton production can be consumed by heterotrophic planktonic grazers (Dupuy et al., 2000). Phytoplankton from this oyster farming area showed higher annual Rubisco activity, normalised to chlorophyll $a$, than phytoplankton from outside oyster farming and offshore areas (Fouilland et al., 1995). A marked effect of the oyster farming zone on bacterial activities has been shown at the water-sediment interface with strong reductive processes contributing to high ammonium concentrations in the farming areas (Gilbert et al., 1997). A higher average ambient ammonium concentration in this area than outside was suggested to explain the strong autotrophic activity (Fouilland et al., 1995). 


\section{Experimental set-up}

The present experiment was conducted at Station ZA (8.5 m depth), located inside the eastern shellfish-farming zone, previously described in Souchu et al. (1997). Two hundred litres of seawater were taken from a $1 \mathrm{~m}$ depth in the middle of the Northern oyster rearing area (Fig. 1) early in the morning. Bulk water was filtered through a $200 \mu \mathrm{m}$ mesh nylon net to remove large particles and macrozooplankton grazers before distribution in incubation carboys. The water was subdivided into eight $20 \mathrm{~L}$ polycarbonate carboys, two carboys per treatment being used to increase the volume of incubated seawater: 40 litres each for control, ammonium, nitrate and taurine enrichments. One carboy of each series was sampled during the first 10 hours of the experiment (carboy A) and the second one during the last 14 hours (carboy B). The reproducibility for a pair of carboys has been tested on chlorophyll $(a+b+c)$ concentrations under all $\mathrm{N}$ treatments and in the control during the experiment. The equation of the linear regression obtained between the Chl concentrations measured from all the carboys A and B is (Chl carboy A) $=0.95$ (Chl carboy $B)+0.02$ with a regression coefficient $\mathrm{R}^{2}=0.988$ indicating that chlorophyll concentrations in a pair of carboys were very similar. Polycarbonate carboys, giving an average of 95\% light transmission, were preferred to glass. All incubated carboys (except control) were enriched in different nitrogen sources with nitrate (10 $\mu \mathrm{M} \mathrm{NaNO}_{3}$ final enhancement), ammonium (10 $\mu \mathrm{M} \mathrm{NH}_{4} \mathrm{Cl}$ final enhancement) and taurine (10 $\mu \mathrm{M}$ final enhancement). Carboys were incubated at in situ temperature and irradiance, at $1 \mathrm{~m}$ depth in the middle of the oyster rearing area. The experiment began on 22 June 1995 at 10:00 (local time) ( $\left.\mathrm{T}_{0}\right)$ until 23 June 1995 at 10:00 $\left(\mathrm{T}_{24}\right)$. The sub-samplings occurred for each incubated carboys at $\mathrm{T}_{0}, \mathrm{~T}_{2}(12: 00), \mathrm{T}_{4}(14: 00), \mathrm{T}_{7}(17: 00), \mathrm{T}_{10}(20: 00), \mathrm{T}_{13}$ (23:00), $\mathrm{T}_{17}(3: 00), \mathrm{T}_{21}$ (7:00) and $\mathrm{T}_{24 .}$ 


\section{$\underline{\text { Physical and chemical variables }}$}

Surface photosynthetic available radiation (PAR) was measured with a LI-COR (Model LI-190SA) quantum sensor and a LI-1000 data logger. Underwater irradiance was measured every $50 \mathrm{~cm}$ with a LI-COR (Model 193SA) spherical quantum sensor. The visible light extinction coefficient was calculated from linear regressions of irradiance vs. depth.

Samples for ammonium $\left(\mathrm{NH}_{4}^{+}\right)$determination were immediately fixed and measured at the laboratory using the method of Koroleff (1976). For the other nutrients, samples were brought to the field laboratory, stored in acid precleaned polycarbonate carboys. Filtrations and storage of samples were performed within one hour after sampling, in an all glass filtering system through a precombusted $\left(450^{\circ} \mathrm{C}\right.$ for $6 \mathrm{~h}$ ) Whatman $\mathrm{GF} / \mathrm{F}$ filter (vacuum $<10 \mathrm{~cm} \mathrm{Hg}$ ). Filtrates were immediately frozen in precombusted Pyrex flasks for later analysis of Soluble Reactive Phosphorus (SRP), nitrate $\left(\mathrm{NO}_{3}^{-}\right)$and nitrite $\left(\mathrm{NO}_{2}^{-}\right)$and silicate with a segmented flow analyser

(Tréguer and Le Corre, 1975). The determination of dissolved organic nitrogen concentration (DON) was performed using the photo-oxidation method (Armstrong and Tibbits, 1968). Determinations of particulate organic carbon (POC) were performed on Whatman 25 mm GF/F filters with a Perkin-Elmer Model 2400 CHN analyzer.

\section{$\underline{\text { Size fractionated filtrations }}$}

For each sampling time, $1050 \mathrm{ml}$ was used for size fractions following a protocol described in Fouilland et al. (2001). This protocol allows;

1) study of the effect of $\mathrm{N}$ treatment on in vitro carboxylase activities for $<1 \mu \mathrm{m}$ and $>1 \mu \mathrm{m}$ plankton cells. 2) expression of the in vitro carboxylase activities per unit cell for $<1 \mu \mathrm{m}$ picophytoplankton. 3) a check for potential filtration artefacts. Two successive filtrations on 
Nuclepore filter ( $1 \mu \mathrm{m}$ size pore) and on GF/F glass fiber Whatman filter ( $0.7 \mu \mathrm{m}$ size pore) with a vacuum $<23 \mathrm{~cm} \mathrm{Hg}$ to minimise cell damage, were performed. Subsamples for cell enumeration were taken before and after filtrations on $1 \mu \mathrm{m}$ Nuclepore and GF/F Whatman filters. Both filters for in vitro carboxylase activities and chlorophyll measurements as well as subsamples fixed previously by $2 \%$ (final concentration) formaldehyde for cell enumeration (Troussellier et al., 1995) were all stored in liquid nitrogen.

\section{Chlorophyll concentration measurements}

Filters were ground in $90 \%$ acetone and extracted for $24 \mathrm{~h}$ in the dark at $4^{\circ} \mathrm{C}$. Chlorophyll $(a+b+c)$ concentrations (Chl) were determined by spectrofluorimetry (Neveux and Lantoine, 1993).

Planktonic cell enumeration and diatoms taxonomy

Subsamples (20 ml) were fixed with $2 \mathrm{ml}$ of $40 \%$ formaldehyde. The samples were kept in the dark at $4^{\circ} \mathrm{C}$. Fixed samples for bacteria and flagellates enumeration were filtered on black polycarbonate Nuclepore membranes (0.22 $\mu \mathrm{m}$ porosity). Five minutes before filtration, one drop of DAPI (4', 6-diamidino-2-phenylindole) was added to samples (Porter and Feig, 1980). Autotrophic and heterotrophic flagellates were discriminated by the red fluorescence of chlorophyll $a$ containing organisms under ultra-violet light using epifluorescence microscopy. Counting was done by examination of 10 equatorial bands (100x objective and band surface: $168000 \mu \mathrm{m}^{2}$ ) over the whole membrane length. For bacteria, 20 to 30 microscope fields were counted in order to have a minimum count of 300 bacteria (100x objective, field surface: 256 
$\mu \mathrm{m}^{2}$ ). Enumeration and identification of large phytoplankton was made by optical microscopy after sedimentation (Utermohl, 1958).

Flow cytometry analyses

Flow cytometry (FCM) analyses were run with an ACR 1000 cytometer. Phytoplanktonic cells were detected according to their light scatter (related to cell size and structure), their orange and red fluorescence emissions (due to phycoerythrin and chlorophyll pigments) collected through 585/42 nm band pass and $650 \mathrm{~nm}$ long pass optical filters, respectively. One $\mu \mathrm{m}$ beads (Polysciences, Warrington, PA), used as internal standard, were systematically added to analyse samples in order to normalise and compare the different phytoplanktonic groups. Flow cytometry allowed us to discriminate phytoplankton with size range between $0.5 \mu \mathrm{m}$ and $50 \mu \mathrm{m}$ (FCM injector size).

\section{$\underline{\text { In vitro carboxylase activities }}$}

The pool of potentially active enzymes responsible for $\mathrm{CO}_{2}$ fixation in plankton community was measured as the in vitro carboxylases activity by incorporation of radioactive bicarbonate into stable products following Descolas-Gros and Oriol (1992). This allowed us to quantify the in vitro Rubisco activity and ß-carboxylase activity (sum of the activities of phosphenolpyruvate carboxylase PEPC, phosphoenolpyruvate carboxykinase PEPCK and pyruvate carboxylase PYRC) present in planktonic community (Appleby et al., 1980; Glover, 1989). All carboxylase assays were made on the same extract. Extraction was carried out at $0{ }^{\circ} \mathrm{C}$ and $\mathrm{pH}$ 8, following the protocol described in Descolas-Gros and De Billy (1987). For the Rubisco assay, the reaction mixture contained $50 \mathrm{mM}$ Tricine buffer (pH 8), $5 \mathrm{mM}$ dithiothreitol 
(DTT), $10 \mathrm{mM} \mathrm{MgCl}_{2}, 20 \mathrm{mM} \mathrm{NaH}{ }^{14} \mathrm{CO}_{3}$ and $100 \mu \mathrm{l}$ of the crude extract. For the other three assays, the reaction mixture contained $50 \mathrm{mM}$ Pipes buffer (pH 6.8) instead of the Tricine buffer. Moreover, $5 \mathrm{mM} \mathrm{MnCl}_{2}$ and $5 \mathrm{mM}$ ADP were added for PEPCK assays, and for PYRC assays, 5 $\mathrm{mM} \mathrm{MgCl}_{2}$ and $5 \mathrm{mM}$ ATP were added. All reactions were initiated after a pre-incubation period of 10 min by adding substrates: $2 \mathrm{mM}$ RuBP for Rubisco assay, $5 \mathrm{mM}$ PEP for PEPC and PEPCK assays and $5 \mathrm{mM}$ pyruvate for PYRC assay. All mixtures were incubated at $25{ }^{\circ} \mathrm{C}$ for 20 min. The reactions were stopped by the addition of $6 \mathrm{~N} \mathrm{HCl}$. More details on the protocol are given in Descolas-Gros and Fontugne (1985), Descolas-Gros and De Billy (1987) and DescolasGros and Oriol (1992). Every carboxylase assay was carried out in triplicate with an assay error $<15 \%$ and was automated with a Gilson auto-analyser (222 Autosampler Injector interfaced with a Dilutor 401). Carboxylase activity is expressed in nmol $\mathrm{CO}_{2} \mathrm{~L}^{-1} \mathrm{~h}^{-1}$, in pmol $\mathrm{CO}_{2} \mu \mathrm{g} \mathrm{C}^{-1} \mathrm{~h}^{-1}$ and in nmol $\mathrm{CO}_{2} \mu \mathrm{g} \mathrm{Chla} \mathrm{C}^{-1} \mathrm{~h}^{-1}$, in order to take into account the variation of the particulate carbon and phytoplanktonic biomass during the experiment and in fmol $\mathrm{CO}_{2}$ cell ${ }^{-1} \mathrm{~h}^{-1}$ when possible. The $\S_{-}$ carboxylases/Rubisco ratio ( $\beta C / \mathrm{R}$ expressed in \%) allowed us to quantify the relative importance of the two pathways.

\section{Experiment reproducibility}

In order to estimate the precision of the biological parameters discussed in this study, the coefficient of variation (CV) has been calculated for each parameter using four values measured at $\mathrm{T}_{0}$ and is presented in Table 1. The $\mathrm{CV}$ of the biological parameters was generally less than $25 \%$, except for the carboxylases activity per cell for diatom cell and for the $\beta$-carboxylase per cell for $<1 \mu \mathrm{m}$ cells with values between 33 and $44 \%$ (Table 1). 


\section{$\underline{\text { Statistical analyses }}$}

In order to compare the effect of $\mathrm{N}$ treatments relative to the control and between the $\mathrm{N}$ treatments, non-parametric Wilcoxon signed-Rank analyses have been applied on cell numbers, chlorophyll concentrations and carboxylase activities and reported in Table 2.

\section{Results}

$\underline{\text { Nutrient concentrations and physical variables }}$

All chemical data are reported in Table 3. Water temperature varied between 22.0 and $23.8^{\circ} \mathrm{C}$ at a depth of $1.5 \mathrm{~m}$. At this depth, the attenuation of the incident light, with a maximum value of $1800 \mu \mathrm{E} \mathrm{m}^{-1} \mathrm{~s}^{-1}$, was about $50 \%$. The initial chemical conditions were characterised by very low concentrations in nitrate $(<0.15 \mu \mathrm{M})$, nitrite $(<0.1 \mu \mathrm{M})$ and by ammonium concentrations averaging $0.4 \mu \mathrm{M}$ and high DON concentrations averaging $24 \mu \mathrm{M}$. These values were close to those reported in June 1993 in the same area (Collos et al., 1997). The phosphate values averaged $0.22 \mu \mathrm{M}$ in all carboys, throughout the experiment (data not shown). The molar ratio of silicate:DIN varied from 17 to 110 in the control and enriched taurine carboys while the ratio was close to 1 (between 0.8 and 2.5) throughout the experiment under enriched $\mathrm{NH}_{4}{ }^{+}$and $\mathrm{NO}_{3}{ }^{-}$treatments (data not shown). This suggested that DIN was the limiting nutrient in the control and enriched taurine carboy during the experiment. The ammonium concentrations decreased from 0.4 to $0.06 \mu \mathrm{M}\left(\mathrm{T}_{10}\right)$ in the control and under $\mathrm{NO}_{3}{ }^{-}$treatment and to $0.17 \mu \mathrm{M}$ ( $\left.\mathrm{T}_{10}\right)$ under taurine treatment and varied between 0.07 to $0.23 \mu \mathrm{M}$ afterwards. The ammonium concentrations decreased from $6.86 \mu \mathrm{M}\left(\mathrm{T}_{0}\right)$ to $0.32 \mu \mathrm{M}\left(\mathrm{T}_{24}\right)$ under $\mathrm{NH}_{4}{ }^{+}$treatment. The nitrate 
remained undetectable throughout most of the experiment in the control, $\mathrm{NH}_{4}{ }^{+}$and taurine treatments and decreased from $9.31 \mu \mathrm{M}\left(\mathrm{T}_{0}\right)$ to $2.42 \mu \mathrm{M}\left(\mathrm{T}_{24}\right)$ under $\mathrm{NO}_{3}{ }^{-}$treatment. The DON concentrations remained quite constant in the control and under DIN treatments, varying from 21.8 to $26.8 \mu \mathrm{M}$ and decreased from $37.6 \mu \mathrm{M}\left(\mathrm{T}_{0}\right)$ to $30.3 \mu \mathrm{M}\left(\mathrm{T}_{24}\right)$ under the taurine treatment.

\section{$\underline{\text { Size fractionation accuracy }}$}

Using the chlorophyll parameter (red fluorescence) from flow cytometry analysis on samples before and after $1 \mu \mathrm{m}$ nuclepore filtration, and compared to the $<1 \mu \mathrm{m}$ chlorophyll $a$ concentrations measured by spectrofluorimetry, the accuracy of size-fractionation protocol was assessed. The red fluorescence for each cell group in the $<1 \mu \mathrm{m}$ fraction was summed and compared with the $<1 \mu \mathrm{m}$ chlorophyll $a$ concentrations. A positive linear regression was obtained $\left(\mathrm{R}^{2}=0.74, \mathrm{n}=22\right)$. The total red fluorescence of cells after $1 \mu \mathrm{m}$ filtration detected by flow cytometry was thus directly correlated with chlorophyll $a$ pigment concentration measured in this $<1 \mu \mathrm{m}$ fraction. This indicates that the potential filtration artefacts (e.g. breakdown of small cells) were reduced during the experiment.

\section{$\underline{\text { Small picoplanktonic cells }}$}

In the $<1 \mu \mathrm{m}$ filtrate, a population of small picoeukaryotes was identified and exhibited the same flow cytometric characteristics as the eukaryotic Ostreococcus tauri. This picoeukaryote contributed $95 \%$ of total $<1 \mu \mathrm{m}$ cell numbers. Larger picoeukaryote cells, with a relative red fluorescence and apparent size close to those of $1 \mu \mathrm{m}$ beads, were also detected in this fraction. No cyanobacteria cells were detected by either flow cytometry or epifluorescence microscopy during this study. The variation of $<1 \mu \mathrm{m}$ cell numbers detected by flow cytometry is reported in 
Table 4. The abundance of small picoeukaryote cells measured during this experiment was in the same range of values as previously observed in the same area between 1991 and 1994, averaging $30 \times 10^{6}$ cell L ${ }^{-1}$ (Vaquer et al., 1996). Compared to the control, no effect of taurine treatment was detected on the $<1 \mu \mathrm{m}$ cell concentrations (Table 2 ). The $<1 \mu \mathrm{m}$ cell numbers increased in all carboys $T_{0}$ to $T_{7}$ and afterwards decreased in the control and under taurine treatment. From $T_{10}$, a strong significant increase of $<1 \mu \mathrm{m}$ cell numbers reaching $5010^{6}$ cell $\mathrm{L}^{-1}$ was observed under DIN treatments (Table 4).

From previous filtration experiments with plankton community from Thau Lagoon, 67 to 74\% of total bacteria cells can be retained on GF/F filters (unpubl. data). Bacterial cell numbers varied slightly during the experiment (Table 3). As compared to the control, the different $\mathrm{N}$ treatments did not influence the cell concentrations. Retention on GF/F filter of $70 \%$ of total bacterial cell was assumed. Thus, the contribution of bacteria cells was always greater than 95\% of the total $<1 \mu \mathrm{m}$ plankton cell numbers retained on $\mathrm{GF} / \mathrm{F}$ filters.

\section{Larger plankton cells community}

At the beginning of the experiment, nano- and microplankton species were dominated by autotrophic flagellates and diatoms, mainly composed of Chaetoceros spp., Skeletonema spp. and Pseudo-nitzschia spp. (Table 5). At the end of the experiment, heterotrophic and autotrophic flagellate abundance did not vary whereas diatom cells reached $1.910^{6}$ cells $\mathrm{L}^{-1}$ in the control and under taurine treatment, mainly due to an increase of Pseudo-nitzschia spp. cells. On the last day of the experiment, higher diatom cell abundance was measured under DIN treatments, mainly due to the increase of Skeletonema spp. cells (Table 5). Using a C/cell conversion factors for each group from Dupuy et al. (2000), the contribution of $>1 \mu \mathrm{m}$ picophytoplankton and diatom 
cells to the total $>1 \mu \mathrm{m}$ planktonic organic carbon was estimated to be less than $0.1 \%$ and greater than 95\%, respectively, during the experiment.

Chlorophyll pigment concentrations and in vitro carboxylases activity

The chlorophyll pigment concentrations and the pool of Rubisco per litre for both size fractions were not significantly different between the control and the taurine treatment, throughout the experiment (Table 2). Compared to the control, a significant increase of chlorophyll concentration occurred after 7 incubation hours under DIN treatments, reaching 10.9 and $0.8 \mu \mathrm{g} \mathrm{L}^{-1}$ for $>1 \mu \mathrm{m}$ and $<1 \mu \mathrm{m}$ phytoplankton cells respectively (Fig. 2A \& 2B, Table 1). Similarly to the chlorophyll concentrations, after 7 incubation hours, the pool of Rubisco per litre for both size fractions was significantly greater under DIN treatments than in the control (Table 2 and 6). The pool of $\beta$-carboxylase activity per litre for both size fractions varied slightly during the 24 hours incubation (Table 7) and no significant different between the $\mathrm{N}$ treatments and the control was reported (Table 2). The values of the total carboxylases activity (i.e. sum of two size fractions) were normalised per carbon using the particulate organic carbon concentration (POC) and reported in Figure 3. In the carboys without DIN enrichments, the total $\beta$-carboxylase activity per carbon increased during the night period, while the total Rubisco activity per carbon decreased (Fig. 3A). A coupling between the total Rubisco and $\beta$-carboxylase activity per carbon was generally observed in the carboys with DIN enrichments (Fig. 3B). The ratio between POC and chlorophyll a concentrations (POC/Chla) decreased from about 700 to $200 \mu \mathrm{gC} \mu \mathrm{gChl}{ }^{-1}$ overall the experiment, in all the carboys. The carboxylases activity was normalised to chlorophyll $a$ concentrations for each size fraction, in order to take into account the phytoplankton biomass variation between the $\mathrm{N}$ treatments during the present experiment. The 
Rubisco activity per Chla generally decreased in all $\mathrm{N}$ treatments for both size fractions during the experiment (Fig. 4) and no significant difference between these $\mathrm{N}$ treatments was measured (Table 2). The $\beta$-carboxylase activity per Chla for both sized fractions generally decreased during the 10 first hours of the experiment in all $\mathrm{N}$ treatments (Fig. 5). Nevertheless, a significant increase of the $\beta$-carboxylase activity per Chla for both size fractions occurred under DIN treatments afterwards, while this activity per Chla remained very low in the control and the taurine treatment (Fig. 5 and Table 2).

\section{$\beta$-carboxylation pathway}

$\beta$-carboxylase activity (PEPC+PEPCK+PYRC) for the plankton community expressed as a percentage of Rubisco activity ( $\beta \mathrm{C} / \mathrm{R}$ ratio) reached values greater than $50 \%$ after 10 incubation hours in the control and under taurine treatment (Fig. 6). Under DIN treatments, the $\beta \mathrm{C} / \mathrm{R}$ ratio for both size fractions was significantly lower than measured in the control with values less than 40\% throughout the study (Table 2). Phosphenolpyruvate carboxylase (PEPC) enzyme contributed to about $50 \%$ of the total $\beta$-carboxylase enzymes in both size fractions (data not shown).

\section{Cellular pool of carboxylase enzymes}

A strong decrease of the Rubisco pool per unit cell was measured in small phytoplankton in all carboys during the experiment and no significant influence of $\mathrm{N}$ treatments was observed (Table 2 and 8). As diatom cells contributed for the most part of carbon biomass in $>1 \mu \mathrm{m}$ plankton community, the in vitro Rubisco activity for $>1 \mu \mathrm{m}$ fraction is expressed on the basis of 
diatom cell number. Similarly to the small cells, a decrease of the Rubisco pool per unit cell is also observed for larger cells after 24 incubation hours in the carboys (Table 5).

For the small size fraction, the enzymatic pool of PEPC is expressed per unit cell of small

picoeukaryotes and reported in the Table 8 . This cellular pool tended to be significantly different between the DIN treatments and the control ( $\mathrm{p}=0.05$ and 0.08 , Table 2). This pool decreased during the experiment under DIN treatments while the highest values in the control and under taurine treatment were recorded close to the end of the experiment (Table 8). The pool of PEPCK is expressed by unit of diatom cells as this enzyme is present in the dominant diatom species observed during this study (Descolas-Gros and Oriol, 1992) and these species contributed to 95\% of the total $>1 \mu \mathrm{m}$ carbon biomass. Similarly to the PEPC in small cells, the cellular pool of PEPCK in larger cells was significantly very low under DIN treatments relative to the control and to the carboy with an addition of taurine at the end of the experiment (Table 5).

\section{Discussion}

After 10 hours of incubation, the very low available dissolved inorganic nitrogen (DIN) concentrations probably limited the growth of phytoplankton in the control and under taurine treatment. This explains the decrease of the small picophytoplankton cells and the low net growth rate of diatoms in these carboys. Nevertheless bacterial cells and heterotrophic flagellates submitted to these different nutrient conditions did not show a net growth rate. In contrast, the net growth rate of picophytoplankton and diatom was about 1.5 and 3 div./day, respectively, in the samples enriched with DIN. 
Even though phytoplankton growth was positively influenced by DIN enrichments, the cellular pool of potentially active Rubisco enzyme for picophytoplankton and diatom cells decreased throughout the study in all the carboys. This suggests a degradation of the cellular enzymatic pool in phytoplankton cells during the study. The rapid degradation of the nitrogen fraction in phytoplankton cells under high irradiance has been shown in a shallow environment with photosynthetically available radiation levels above 600 to $1000 \mu \mathrm{E} \mathrm{m}^{-2} \mathrm{~s}^{-1}$ (Collos et al., 1992). Rubisco enzyme can act as a nitrogen reservoir that is more easily mobilised than the rest of the protein pool during environmental changes (Ekman et al., 1989). Thus, cellular Rubisco pool degradation during this present study may result from the light conditions in incubation carboys held at fixed positions near the surface where phytoplankton cannot avoid high irradiance levels during the day time reaching about $900 \mu \mathrm{E} \mathrm{m}^{-2} \mathrm{~s}^{-1}$ at the incubation depth.

As compared to the Rubisco pathway, the potential use of $\beta$-carboxylation pathway by the plankton community, as shown by the carboxylases activity normalised to the particulate carbon, chlorophyll $a$ and cell and by the ratio $\beta \mathrm{C} / \mathrm{R}$, increased after 10 incubation hours in the carboys without DIN enrichments only. The values of the $\beta C / R$ ratio were higher than $100 \%$, at which time, the phytoplankton biomass started to decrease in the control and under taurine treatment. In contrast, $\beta$-carboxylase activity seemed strongly coupled to the Rubisco activity under DIN treatments. This daily co-variation was already reported for natural phytoplankton in Mediterranean Sea under favourable environmental conditions (Fouilland et al., 2001), showing the strong interdependence of these two C assimilation pathways (falkowski and Raven, 1997). The $\beta C / R$ ratio under DIN treatments remained less than $40 \%$, which is a characteristic of autotrophic cells (Descolas-Gros and Oriol, 1992). A $\beta$ C/R ratio higher than $100 \%$ suggests that the $\beta$-carboxylation pathway can prevail on the Calvin-Benson pathway. As $\beta$-carboxylation in 
the light occurs using a substrate (PEP) derived from the Calvin-Benson cycle, a ratio greater than $100 \%$ has been associated with the occurrence of heterotrophic organisms, such as dinoflagellates (Descolas-Gros and Oriol, 1992). For such cells, the origin of phosphoenolpyruvate is uncertain and Descolas-Gros and Oriol (1992) suggested that it could be supplied by the incorporation of external organic substances.

The increase of $\beta$-carboxylase pathway observed in the present study cannot be explained by the increase of heterotrophic biomass relative to the autotrophic biomass in the control or with addition of taurine. The POC/Chla ratio decreased throughout the experiment, suggesting a shift towards an autotrophic community in all the carboys. For the small size fraction, bacterial cells, which are partially retained by filters, could have significantly contributed to the total $\beta$ carboxylase activity as suggested by results from dark fixation of ${ }^{14} \mathrm{C}$ from natural plankton (Li et al., 1993; Markager, 1999). Nevertheless the regulation of $\beta$-carboxylation pathway and enzyme structure is different in bacterial and phytoplankton cells (Rivoal et al., 1998). The occurrence of carboxylation of PEP by PEPC is well known in bacterial cells. Nevertheless this carboxylase does not act unless acetyl-coenzyme A is present, perhaps to facilitate a continued supply of oxaloacetate for the TCA cycle fuelling (Baumerg, 1973; Overbeck, 1984). Such regulation does not occur in phytoplankton cells (Turpin et al., 1991). As no acetyl-coenzyme A is added to the reaction mixture, the strong variation of the activity of major $\beta$-carboxylase enzymes (PEPC) is assumed to be directly related to the $\beta$-carboxylation pathway of the small picoeukaryote cells. Moreover the bacterial cells contributed a very large fraction to the total $<1 \mu \mathrm{m}$ picoplankton abundance and no significant difference in the bacterial abundance was noticed between carboys (Table 4). Thus, any increase of $\beta C / \mathrm{R}$ ratio for the $<1 \mu \mathrm{m}$ fraction observed after 10 hours of incubation cannot be due to the bacterial growth relative to the decrease of small 
picophytoplankton abundance which contributed to less than $5 \%$ of total cell numbers over the experiment in all carboys. The importance of bacterial activity (free or attached bacteria cells) is assessed relatively to the ammonium uptake. Data from Table 3 show that ammonium uptake was at least twice as high during the day than at night in $\mathrm{NH}_{4}{ }^{+}$treatment, indicating autotrophic driven processes. In the control, ammonium actually increased at night (Table 3), so it can be safely assumed that bacterial populations produced rather than consumed ammonium in these series of experiment. This suggests that the heterotroph bacterial activity was not influenced by the $\mathrm{N}$ treatments. Moreover, using values for the carbon content in plankton species in Thau Lagoon calculated by Dupuy et al. (2000), the heterotroph flagellates contributing to the total $>1$ $\mu$ m plankton biomass was estimated to be less than $1 \%$ in the control and under all $\mathrm{N}$ treatments at the end of the experiment. Thus, the variation of the $\beta$-carboxylation enzyme pool relative to the Rubisco was mainly due to the enzyme activities from the autotrophic plankton in both size fractions.

Anaplerotic carbon fixation by PEPC in the light exceeding photosynthetic carbon fixation has already been measured in an $\mathrm{N}$-limited green alga using stable carbon isotope discrimination (Guy et al., 1989). These authors showed that under transient situations the contribution of $\beta$-carboxylation to the total $C$ fixation can be as high as $70 \%$, i.e. a $\beta C / R$ ratio of $230 \%$, which is higher than our maximum value for a natural plankton assemblage (160\%). The significant increase of both $\beta C / R$ ratio and the $\beta$-carboxylase activity normalised to the chlorophyll and carbon biomass reported during the present study, suggests a potential increase of cellular $\beta$-carboxylase enzymes. The pool of PEPC and PEPCK expressed per unit cell for the small picoeukaryotes and diatoms tended to increase at the end of the experiment in the control and under taurine treatment. This increase of the activity of $\beta$-carboxylase enzymes combined 
with the decrease of the Rubisco activity under inorganic N-deficient conditions suggests that $\beta$ carboxylation pathway is more active when phytoplankton growth is limited by inorganic nutrients. A higher photosynthetic carbon fixation by $\beta$-carboxylation than by Rubisco in autotrophic phytoplankton cells is surprising, especially in regards to the source of the substrate for $\beta$-carboxylation. The dissimilation of reserve carbohydrate providing PEP for this pathway, as usually observed in the dark for microalgae (Mortain-Bertrand et al., 1988), is unlikely. This is because phytoplankton growth was very low under N-deficient conditions, implying low C storage in cells.

The increase of the enzymatic pool for $\beta$-carboxylation in phytoplankton may be due to a shift from autotrophic to heterotrophic activity induced by a DIN deficiency as in the control and DON (taurine) treatment. There is indirect evidence that taurine was taken up during the day. Data from Table 2 shows that DON decreased in the carboys enriched with taurine, while it remained constant in the others. This decrease roughly corresponds to the taurine addition, but taurine was taken up during the day only, and not at night, which indicates that phytoplankton, not bacteria, were responsible for this uptake. Nevertheless, this uptake does not result in increased phytoplankton biomass as observed in enriched ammonium or nitrate carboys. Possibly, the time lag involved between uptake and growth is longer than the time scale used in the present study as observed elsewhere (Antia et al., 1975; Bonin and Maestrini, 1981). Thus, increases in cell numbers could not be observed within a 24-hour time frame following the

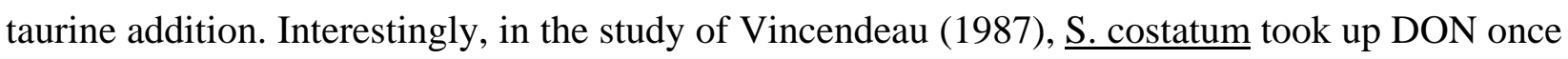
DIN was exhausted. Thus, the similarity between the control and the taurine treatment could have a common explanation: heterotrophy is induced by DIN limitation. The increase of $\beta$ carboxylation pathway under limiting $\mathrm{N}$ conditions is coupled to the uptake of dissolved nitrogen 
compounds by phytoplankton, resulting in the activation of respiration for the biosynthetic processes. This causes the back-regulation of anaplerotic reactions, as previously described by Vanlerberghe et al. $(1990,1992)$ for $\mathrm{NH}_{4}{ }^{+}$uptake. A stimulation of respiration after the addition of acetate has also been observed in Chlamydomonas reinhardtii, cultured photoautotrophically (Fett and Coleman, 1994; Endo and Asada, 1996). Moreover, under similar conditions, Heifetz et al. (2000) showed a decrease of photosynthetic carbon fixation in cells grown in acetate with saturating light and $\mathrm{CO}_{2}$. These results suggest an increase of the $\beta$-carboxylation pathway for the replenishment of TCA cycle intermediates, in order to sustain the growth rate of $\underline{\mathrm{C} \text {. reinhardtii }}$ growing heterotrophically, using acetate as source of carbon. This is in accordance with the increase of cellular $\beta$-carboxylase pool during a shift toward heterotrophy, in natural phytoplankton cells suggested in this study. Even though the evidence of this heterotrophy was observed with the taurine enrichment only, the importance of the $\beta$-carboxylation pathway in natural phytoplankton under very low nutrient conditions is clearly highlighted in this study. In order to gain further insight into the phytoplankton heterotrophy, the relationship between the $\mathrm{CO}_{2}$ assimilation pathways and the capacity of phytoplankton to use organic sources of nitrogen and/or carbon should be investigated using axenic cultures of phytoplankton submitted to different nutritional conditions, for instance.

\section{Acknowledgements}

This work was supported by CNRS, University Montpellier II, IFREMER (URM 5). We thank J-M. Deslous-Paoli and C. Leboulanger for their assistance during the fieldwork; т. Sime- 
Ngando for providing bacteria and flagellates data and 2 anonymous referees for insightful comments on the manuscript. This paper represents a portion of a thesis of the University Paris VI of Eric Fouilland who received a BDI fellowship from CNRS and IFREMER. This is the XXX ISEM contribution for Chantal Descolas-Gros. 


\section{References}

Appleby, G., Colbeck, J., Holdsworth, E.S., Wadman, H., 1980. ßcarboxylation enzymes in marine phytoplankton and isolation and purification of pyruvate carboxylase from Amphidinium carterae (Dinophyceae). J. Phycol. 16, 290-295.

Antia, N.J., Berland, B.R., Bonin, D.J., Maestrini, S.Y., 1975. Comparative evaluation of certain organic and inorganic sources of nitrogen for phototrophic growth of marine microalgae. J. Mar. Biol. Ass..U K 55, 519-539.

Armstrong, F.A.J., Tibbits, S., 1968. Photochemical combustion of organic matter in sea water for nitrogen phosphorus and carbon determination. J. Mar. Biol. Ass. U K 48, $143-152$.

Bacher, C., Millet, B., Vaquer, A., 1997. Modélisation de l'impact des mollusques cultivés sur la biomasse phytoplanctonique de l'étang de Thau (France). C. R. Acad. Sci. Paris, 320, 73-81.

Baumberg, S., 1973. Co-ordination of metabolism. In: Mandelstam J, McQuillen K (eds) Biochemistry of bacterial growth. Second edition, Blackwell, 423-493.

Bonin, D.J., Maestrini, S.Y., 1981. Importance of organic nutrients for phytoplankton growth in natural environments: implications for algal species successionPhysiological bases of phytoplankton ecology. . Platt, T. (Ed). Can. Bull. Fish. Aquat. Sci. 210, 279-291

Chrétiennot-Dinet, M.-J., Courties, C., Vaquer, A., Neveux, J., Claustre, H., Lautier, J., Machado, M.C., 1995. A new marine picoeukaryote: Ostreococcus tauri gen et sp nov (Chlorophyta Prasinophyceae). Phycologia 34, 85-292. 
Collos, Y., Descolas-Gros, C., Fontugne, M., Mortain-Bertrand, A., Chretiennot-Dinet, M.J., Frikha, M.G., 1992. Carbon and nitrogen dynamics during growth and degradation of phytoplankton under natural surface irradiance. Mar. Biol. 112, 491-496.

Collos, Y., Descolas-Gros, C., Fontugne, M., Mortain-Bertrand, A., Chrétionnot-Dinet, M.-J., Frikha, M.G., 1993. Chemical isotopic and enzymatic monitoring of free and enclosed seawater: implications for primary production estimates in incubation carboys. Mar. Ecol. Prog. Ser. 93, 49-54.

Collos, Y., Vaquer, A., Bibent, B., Slawyk, G., Garcia, N., Souchu, P., 1997. Variability in nitrate uptake kinetics of phytoplankton communities in a Mediterranean coastal lagoon. Estuar. Coast. Shelf S. 44, 369-375.

Courties, C., Vaquer, A., Troussellier, M., Lautier, J., Chrétiennot-Dinet, M.-J., Neveux, J., Machado, C., Claustre, H., 1994. Smallest eukaryotic organism. Nature 370, 255.

Descolas-Gros, C., Fontugne, M., 1985. Carbon fixation in marine phytoplankton: carboxylase activities and stable carbon-isotope ratios; physiological and paleoclimatological aspects. Mar. Biol. 87, 1-6.

Descolas-Gros, C., De Billy, G., 1987. Temperature adaptation of RuBP caboxylase: kinetic properties in marine Antarctic diatoms. J. Exp. Mar. Biol. Ecol. 108, 147-158.

Descolas-Gros, C., Oriol, L., 1992. Variations in carboxylase activity in marine phytoplankton cultures ßcarboxylation in carbon flux studies. Mar. Ecol. Prog. Ser. 85, 163-169.

Dodds, W.K., Priscu, J.C., 1991. Ammonium stimulation of dark carbon fixation as an indicator of nitrogen deficiency in phytoplankton: potential errors caused by ammonium-oxidizing bacteria. J. Phycol. 27, 79-82. 
Dupuy, C., Vaquer, A., Lam-Hoai, T., Rougier, C., Mazouni, N., Lautier, J., Collos, Y., Le Gall, S., 2000. Feeding rate of the oyster Crassostera gigas in a natural planktonic community of Mediterranean Thau Lagoon. Mar. Ecol. Prog. Ser. 205, 171-184.

Ekman, P., Lignell, A., Pedersen, M., 1989. Localization of ribulose-1,5-bisphosphate carboxylase/oxygenase in Gracilaria secundata (Rhodophyta) and its role as a nitrogen storage pool. Botanica Mar. 32, 527-534.

Elrifi, I.R., Turpin, D.H., 1986. Nitrate and ammonium induced photosynthetic suppression in Nlimited Selenastrum minutum. Plant Physiol. 81, 273-279.

Endo, T., Asada, K., 1996. Dark induction of the non-photochemical quenching of chlorophyll fluorescence by acetate in Chlamidomonas reinhardtii. Plant Cell Physiol. 37, 551-555.

Falkowski, P.G., Raven, J.A., 1997. Aquatic photosynthesis. Blackwell Science publisher

Fett, J.P., Coleman, J.R., 1994. Regulation of periplasmic carbonic anhydrase expression in Chlamidomonas reinhardtii by acetate and pH. Plant Physiol. 106, 103-108.

Fidalgo, J.P., Cid, A., Abalde, J., Herrero, C., 1995. Culture of the marine diatom Phaedactylum

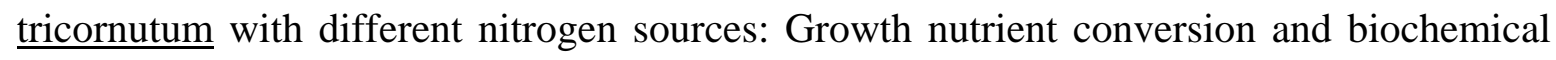
composition. Cah. Biol. Mar. 36, 165-173.

Fouilland, E., Vaquer, A., Descolas-Gros, C., 1995. Annual variations in $\mathrm{CO}_{2}$ assimilation and primary production measurements in a mediterranean lagoon (Thau lagoon France). Photosynthesis: from Light to Biosphere. Mathis, P. (Ed.). Elvesier 5, 873-876.

Fouilland, E., Courties, C., Descolas-Gros, C., 2001. Size-fractionated carboxylase activities during a $32 \mathrm{~h}$ cycle at $30 \mathrm{~m}$ depth in the Northwestern Mediterranean Sea after an episodic wind event. J. Plankton Res. 23, 623-632. 
Gasc, A., 1997. Etude de la production primaire régénérée dans un écosystème conchylicole: le bassin de Thau. Ph. D Univ Sciences et Techniques du Languedoc, Montpellier, France.

Gilbert, F., Souchu, P., Bianchi, M., Bonin, P., 1997. Influence of shellfish farming activities on nitrification nitrate reduction to ammonium and denitrification at the water-sediment interface of the Thau lagoon France. Mar. Ecol. Prog. Ser. 151, 143-153.

Glover, H.E., 1989. Ribulosebisphosphate carboxylase/oxygenase in marine organisms. Int. Rev. Cytol. 115, 67-137.

Guy, R.D., Vanlerberghe, G.C., Turpin, D.H., 1989. Significance of phosphoenolpyruvate carboxylase during ammonium assimilation Carbon isotope discrimination in photosynthesis and respiration by the N-limited green alga Selenastrum minutum. Plant Physiol. 89, 1150-1157.

Heifetz, P.B., Forster, B., Osmond, C.B., Giles, L.J., Boynton, J.E., 2000. Effects on facultative autotrophy in Chlamydomonas reihardtii assessed by photosynthetic measurements and stable isotope analyses. Plant Physiol. 122, 1439-1445.

Huppe, H.C., Turpin, D.H., 1994. Integration of carbon and nitrogen metabolism in plant and algal cells. Annu, Rev, Physiol, Plant Mol, Biol, 45, 577-607.

Koroleff, F., 1976. Determination of nutrients. Methods of Seawater analysis. Grasshoff, K. (Ed.), Verlag Chemie, 117-182.

Lam-Hoai, T., Rougier, C., Lasserre, G., 1997. Tintinnids and rotifers in a northern Mediterranean coastal lagoon. Structural diversity and function through biomass estimations. Mar. Ecol. Prog. Ser. 152, 13-25. 
Le Gall, S., Hassen, M.B., Le Gall P.B., 1997. Ingestion of a bacterivorous ciliate by oyster Crassostera gigas: protozoa as a trophic link between picoplankton and benthic suspensionfeeders. Mar. Ecol. Prog. Ser. 152, 301-306.

Levasseur, M., Thompson, P.A., Harrison, P.J., 1993. Physiological acclimation of marine phytoplankton to different nitrogen sources. J. Phycol. 29, 587-595.

Millet, B.. 1989. Fonctionnement hydrodynamique du bassin de Thau. Validation d'un modèle numérique de circulation (programme Ecothau). Oceanol. Acta 12, 37-46.

Morris, I., Yentsch, C.M., Yentsch, C.S., 1971. The physiological state with respect to nitrogen of phytoplankton from low-nutrient subtropical water as measured by the effect of ammonium ion on dark carbon dioxide fixation. Limnol. Oceanogr. 16, 859-868.

Mortain-Bertrand, A., Descolas-Gros, C., Jupin, H., 1987a. Short-term ${ }^{14} \mathrm{C}$ incorporation in Skeletonema costatum (Greville) Cleve (Bacillariophyceae) as a function of light regime. Phycologia 16, 262-269.

Mortain-Bertrand, A., Descolas-Gros, C., Jupin, H., 1987b. Stimulating effect of transitions from light to dark on carbon assimilation by a marine diatom. J. Exp. Mar. Biol. Ecol. 112, 1126.

Mortain-Bertrand, A., Descolas-Gros, C., Jupin, H. 1988. Pathway of dark inorganic carbon fixation in two species of diatoms: influence of light regime and regulator factors on diel variations. J. Plankton Res., 10, 199-217.

Neveux, J., Lantoine, F., 1993. Spectrofluorometric assay of chlorophylls and phaeopigments using the least squares approximation technique. Deep-Sea Res 40, 1747-1765. 
Osborne, B.A., Geider, R.J., 1986. Effect of nitrate-nitrogen limitation on photosynthesis of the diatom Phaeodactylum tricornutum Bohlin (Bacillariphyceae). Plant Cell Environ. 9, 617625.

Overbeck, J., 1984. Application of TCA cycle metabolism for growth estimates of heterotrophic bacterioplankton. Arch. Hydrobiol. Beih., 19, 23-36.

Porter, K., Feig, Y.S., 1980. The use of DAPI for identifying and counting aquatic microflora. Limnol. Oceanogr. 25, 943-948.

Slawyk, G., Collos, Y., 1982. 13C and 15N uptake by marine phytoplankton. 2. Results from a tropical area. Rapp. P.-v. Réun. Cons. int. Explor. Mer 180, 209-213

Souchu, P., Gasc, A., Cahet, G., Vaquer, A., Collos, Y., Deslous-Paoli, J.M., 1997. Biogeochemical composition of Mediterranean waters outside the Thau lagoon. Estuar. Coast. Shelf S. 44, 275-284.

Souchu, P., Vaquer, A., Collos, Y., Lamdrein, S., Deslous-Paoli, J.-M., Bibent, B., 2001. Influence of shellfish farming activities on the biogeochemical composition of the water column in Thau Lagoon. Mar. Ecol. Prog. Ser. 218, 141-152.

Tréguer, P., Le Corre, P., 1975. Manuel d'analyse des sels nutritifs dans l'eau de mer Utilisation de l'AutoAnalyseur II Technicon LOC. Université de Bretagne Occidentale Brest, France.

Troussellier, M., Courties, C., Zettelmaier, S., 1995. Flow cytometric analysis of coastal lagoon bacterioplankton and picophytoplankton: fixation and storage effects. Estuar. Coast. Shelf S. $40,621-633$.

Turpin D.H., 1991. Effects of inorganic $\mathrm{N}$ availability on algal photosynthesis and carbon metabolism. J. Phycol. 27, 14-20. 
Turpin, D.H., Vanlerberghe, G.C., Amory, A.M., Guy, R.D., 1991. The inorganic requirements for nitrogen assimilation. Can. J. Bot. 69, 1139-1145.

Utermöhl, H., 1958. Zur Vervollkommnung der quantitativen Phytoplankton-Methodik. Mitt. int. Ver. theor. angew. Limnol. 9, 1-38.

Vanlerberghe, G.C., Schuller, K.A., Smith, R.G., Feil, R., Plaxton, W.C., Turpin, D.H., 1990. Relationship between $\mathrm{NH}_{4}{ }^{+}$assimilation rate and in vivo phosphoenolpyruvate carboxylase activity Regulation of anapleurotic carbon flow in the green alga Selenastrum minutum. Plant Physiol. 94, 284-290.

Vanlerberghe, G.C., Huppe, H.C., Vlossak, K.D.M., Turpin, D.H., 1992. Activation of respiration to support dark $\mathrm{NO}_{3}{ }^{-}$and $\mathrm{NH}_{4}{ }^{+}$assimilation in the green alga Selenastrum minutum. Plant Physiol. 99, 495-500.

Vaquer, A., Troussellier, M., Courties, C., Bibent, B., 1996. Standing stock and dynamics of picophytoplankton in the Thau Lagoon (northwest Mediterranean coast). Limnol. Oceanogr. 41, 1821-1828.

Vincendeau, M.L., 1987. Etude expérimentale de la fertilité des eaux des milieux conchylicoles: influence de l'excrétion des huitres et des palourdes sur la production des diatomées dominantes. Ph. D Univ Paris 6, Paris, France. 
Table 1. Coefficient of variation (in percent) of the different biological parameters calculated using four measurements observed at $\mathrm{T}_{0}$.

* Calculation based on cell numbers of diatom dominant species

\begin{tabular}{ccc}
\hline & $>1 \mu \mathrm{m}$ & $<1 \mu \mathrm{m}$ \\
\hline Cell numbers & $22^{*}$ & 6 \\
Chlorophyll $a$ concentrations & 6 & 10 \\
Rubisco activity per liter & 20 & 17 \\
ß-Carboxylases per liter & 23 & 12 \\
Rubisco activity per chlorophyll $a$ unit & 17 & 24 \\
ß-Carboxylases activity per chlorophyll $a$ unit & 19 & 12 \\
$\beta C /$ R ratio & 23 & 24 \\
Rubisco activity per cell & $35^{*}$ & 18 \\
$\beta$-carboxylase per cell & $44^{*}$ & 33 \\
\hline
\end{tabular}


Table 2. Statistical results from non parametric Wilcoxon signed-Rank analyses between N enriched treatments and control.

${ }^{*} 0.01 \leq \mathrm{p}<0.05,{ }^{* *} \mathrm{p} \leq 0.01$, NS non significant $(\mathrm{p} \geq 0.1)$

\begin{tabular}{|c|c|c|c|c|c|c|c|c|c|c|c|c|c|c|c|}
\hline & \multirow{2}{*}{$\begin{array}{c}\text { Cell } \\
\text { numbers } \\
<1 \mu \mathrm{m}\end{array}$} & \multicolumn{2}{|c|}{$\begin{array}{c}\text { Chl } a \\
\text { concentrations }\end{array}$} & \multicolumn{2}{|c|}{$\begin{array}{c}\text { Rubisco activity } \\
\text { per litre }\end{array}$} & \multicolumn{2}{|c|}{$\begin{array}{c}\beta \text {-carboxylase } \\
\text { activity per litre }\end{array}$} & \multicolumn{2}{|c|}{$\begin{array}{l}\text { Rubisco activity } \\
\text { per Chl } a\end{array}$} & \multicolumn{2}{|c|}{$\begin{array}{c}\beta \text {-carboxylase } \\
\text { activity per Chl } a\end{array}$} & \multicolumn{2}{|c|}{$\beta C / \mathrm{R}$ ratio } & \multirow{2}{*}{$\begin{array}{c}\text { Rubisco activity } \\
\text { per cell } \\
<1 \mu \mathrm{m}\end{array}$} & \multirow{2}{*}{$\begin{array}{c}\text { PEPC activity } \\
\text { per cell } \\
<1 \mu \mathrm{m}\end{array}$} \\
\hline & & $>1 \mu \mathrm{m}$ & $<1 \mu \mathrm{m}$ & $>1 \mu \mathrm{m}$ & $<1 \mu \mathrm{m}$ & $>1 \mu \mathrm{m}$ & $<1 \mu \mathrm{m}$ & $>1 \mu \mathrm{m}$ & $<1 \mu \mathrm{m}$ & $>1 \mu \mathrm{m}$ & $<1 \mu \mathrm{m}$ & $>1 \mu \mathrm{m}$ & $<1 \mu \mathrm{m}$ & & \\
\hline$+\mathrm{NH}_{4}^{+} /$Control & 0.09 & $* *$ & * & * & * & NS & NS & NS & NS & * & * & $* *$ & * & NS & 0.05 \\
\hline$+\mathrm{NO}_{3}^{-} /$Control & * & * & * & * & * & NS & NS & NS & NS & * & NS & * & * & NS & 0.08 \\
\hline +taurine / Control & NS & NS & NS & NS & NS & NS & NS & NS & NS & NS & NS & NS & NS & NS & NS \\
\hline
\end{tabular}


Table 3. Concentrations of ammonium, nitrate and dissolved organic nitrogen (DON) measured in the control, $\mathrm{NH}_{4}{ }^{+}$ $\left(+\mathrm{NH}_{4}{ }^{+}\right), \mathrm{NO}_{3}{ }^{-}\left(+\mathrm{NO}_{3}{ }^{-}\right)$and taurine (+taurine) enriched treatments during the experiment.

nd: no data; data in bold denote a period of darkness

\begin{tabular}{ccccccccccccc}
\hline & \multicolumn{3}{c}{ Ammonium concentrations $(\mu \mathrm{M})$} & \multicolumn{3}{c}{ Nitrate concentrations $(\mu \mathrm{M})$} & \multicolumn{3}{c}{$\begin{array}{c}\text { Dissolved organic nitrogen (DON) } \\
\text { concentrations }(\mu \mathrm{M})\end{array}$} \\
& Control & $+\mathrm{NH}_{4}^{+}$ & $+\mathrm{NO}_{3}^{-}$ & + taurine & Control & $+\mathrm{NH}_{4}^{+}$ & $+\mathrm{NO}_{3}^{-}$ & + taurine & Control & ${ }^{+} \mathrm{NH}_{4}^{+}$ & $+\mathrm{NO}_{3}^{-}$ & + taurine \\
\hline $\mathrm{T}_{0}$ & 0.39 & 6.86 & 0.4 & 0.47 & 0.13 & 0.05 & 9.31 & 0.03 & 22.6 & 26.8 & 21.8 & 37.6 \\
$\mathrm{~T}_{2}$ & nd & nd & 0.26 & nd & 0.06 & 0.00 & 8.96 & 0.00 & 22.4 & nd & 22.2 & $\mathrm{nd}$ \\
$\mathrm{T}_{4}$ & 0.45 & 5.82 & 0.24 & 0.37 & 0.00 & 0.00 & 8.5 & 0.00 & 22.4 & 25.5 & 23.6 & 36.9 \\
$\mathrm{~T}_{7}$ & 0.11 & 3.52 & 0.22 & 0.29 & 0.00 & 0.00 & 7.46 & 0.00 & 24.7 & 26.6 & 24.5 & 33.2 \\
$\mathrm{~T}_{10}$ & 0.06 & 3.62 & 0.06 & 0.17 & 0.01 & 0.00 & 6.15 & 0.00 & 26.5 & 25.6 & 23.6 & 32.9 \\
$\mathrm{~T}_{13}$ & $\mathbf{0 . 1 1}$ & $\mathbf{3 . 8 4}$ & $\mathbf{0 . 1 5}$ & $\mathbf{0 . 2 3}$ & $\mathbf{0 . 0 0}$ & $\mathbf{0 . 0 0}$ & $\mathbf{6 . 3 3}$ & $\mathbf{0 . 0 0}$ & $\mathbf{2 4 . 9}$ & $\mathbf{2 5 . 8}$ & $\mathbf{2 5 . 1}$ & $\mathbf{3 1 . 2}$ \\
$\mathrm{T}_{\mathbf{1 7}}$ & $\mathbf{0 . 1 8}$ & $\mathbf{3 . 2 7}$ & $\mathbf{0 . 1 2}$ & $\mathbf{0 . 1 5}$ & $\mathbf{0 . 0 0}$ & $\mathbf{0 . 0 8}$ & $\mathbf{5 . 8 6}$ & $\mathbf{0 . 0 1}$ & $\mathbf{2 1 . 8}$ & $\mathbf{2 4 . 9}$ & $\mathbf{2 2 . 1}$ & $\mathbf{3 1 . 5}$ \\
$\mathrm{T}_{21}$ & 0.07 & 2.61 & 0.09 & 0.22 & 0.00 & 0.00 & 4.68 & 0.00 & 23.3 & 26.0 & 22.3 & 31.7 \\
$\mathrm{~T}_{24}$ & 0.17 & 0.32 & 0.19 & 0.20 & 0.00 & 0.00 & 2.42 & 0.00 & 24.4 & 26.0 & 21.8 & 30.3 \\
\hline
\end{tabular}


Table 4. Small picophytoplankton and bacteria cell numbers during the experiment in the control and $\mathrm{N}$ enriched treatments.

nd: no data; data in bold denote a period of darkness

\begin{tabular}{|c|c|c|c|c|c|c|c|c|}
\hline & \multicolumn{4}{|c|}{ 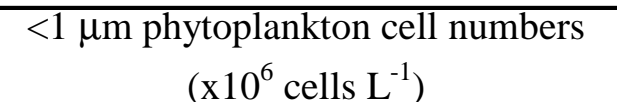 } & \multicolumn{4}{|c|}{$\begin{array}{l}\text { Bacteria cell numbers } \\
\left(\times 10^{6} \text { cells } \mathrm{L}^{-1}\right)\end{array}$} \\
\hline & Control & $+\mathrm{NH}_{4}^{+}$ & $+\mathrm{NO}_{3}^{-}$ & +taurine & Control & $+\mathrm{NH}_{4}^{+}$ & $+\mathrm{NO}_{3}{ }^{-}$ & +taurine \\
\hline $\mathrm{T}_{0}$ & 19.6 & 19.5 & 21.9 & 20.8 & 936 & nd & nd & nd \\
\hline $\mathrm{T}_{2}$ & 18.2 & 20.8 & 18.2 & 13.0 & nd & nd & nd & nd \\
\hline $\mathrm{T}_{4}$ & 30.9 & 25.2 & 27.9 & 25.7 & nd & nd & nd & nd \\
\hline $\mathrm{T}_{7}$ & 30.4 & 33.3 & 31.2 & 28.6 & 1220 & 1220 & 1200 & 1360 \\
\hline $\mathrm{T}_{10}$ & 26.0 & 41.5 & 40.6 & 22.1 & nd & nd & nd & nd \\
\hline $\mathbf{T}_{13}$ & 25.8 & 48.2 & 48.4 & 23.0 & 1500 & 1500 & 1190 & 1330 \\
\hline $\mathbf{T}_{17}$ & 19.8 & 51.6 & 40.9 & 21.9 & nd & nd & nd & nd \\
\hline $\mathrm{T}_{21}$ & 20.8 & nd & 50.0 & 17.7 & 1510 & 1220 & 884 & 1170 \\
\hline $\mathrm{T}_{24}$ & 13.5 & nd & 45.7 & 18.4 & 1120 & 967 & 832 & 1160 \\
\hline
\end{tabular}


Table 5. Plankton cell numbers and carboxylases (Rubisco and PEPCK) activity per carbon unit of diatom cell within the $>1 \mu \mathrm{m}$ fraction at $\mathrm{T}_{0}$ in the control and $\mathrm{T}_{24}$ in the control and $\mathrm{N}$ enriched treatments. nd: no data

\begin{tabular}{|c|c|c|c|c|c|}
\hline & \multirow{2}{*}{$\mathrm{T}_{0}$} & \multicolumn{4}{|c|}{$\mathrm{T}_{24}$} \\
\hline & & Control & $+\mathrm{NH}_{4}^{+}$ & $+\mathrm{NO}_{3}^{-}$ & +taurine \\
\hline Picophytoplankton (x10 cells L ${ }^{-1}$ ) & 2.7 & 14.9 & nd & 20 & 7.2 \\
\hline Heterotroph flagellates (x10 cells L ${ }^{-1}$ ) & 0.6 & 0.5 & 0.3 & 0.2 & 0.5 \\
\hline Autotroph flagellates (x10 cells $\mathrm{L}^{-1}$ ) & 0.7 & 1.1 & 0.6 & 0.5 & 0.7 \\
\hline Diatoms (x10 cells L $\left.{ }^{-1}\right)$ & 0.8 & 1.9 & 9.1 & 5.0 & 1.9 \\
\hline Rubisco activity (fmol CO cell $^{-1} \mathrm{~h}^{-1}$ ) & 117 & 57 & 83 & 112 & 60 \\
\hline PEPCK activity (fmol CO cell $^{-1} \mathrm{~h}^{-1}$ ) & 9.0 & 2.6 & 0.06 & 0.46 & 7.5 \\
\hline
\end{tabular}


Table 6 . The in vitro Rubisco activity per litre of $>1 \mu \mathrm{m}$ and $<1 \mu \mathrm{m}$ fractions in the control and enriched $\mathrm{N}$ treatments.

nd: no data; data in bold denote a period of darkness

\begin{tabular}{|c|c|c|c|c|c|c|c|c|}
\hline & \multicolumn{4}{|c|}{$\begin{array}{c}>1 \mu \mathrm{m} \text { Rubisco activity } \\
\left(\mathrm{nmol} \mathrm{CO}_{2} \mathrm{~L}^{-1} \mathrm{~h}^{-1}\right)\end{array}$} & \multicolumn{4}{|c|}{$\begin{array}{l}<1 \mu \mathrm{m} \text { Rubisco activity } \\
\left(\mathrm{nmol} \mathrm{CO} \mathrm{CO}_{2} \mathrm{~L}^{-1} \mathrm{~h}^{-1}\right)\end{array}$} \\
\hline & Control & $+\mathrm{NH}_{4}^{+}$ & $+\mathrm{NO}_{3}^{-}$ & +taurine & Control & $+\mathrm{NH}_{4}^{+}$ & $+\mathrm{NO}_{3}^{-}$ & +taurine \\
\hline $\mathrm{T}_{0}$ & 108.8 & 66.4 & 84.4 & 93.9 & 51.9 & 45.9 & 49.8 & 34.9 \\
\hline $\mathrm{T}_{2}$ & 121.5 & 132.2 & 114.7 & 153.5 & 28.9 & 43.4 & 42.8 & 34.7 \\
\hline $\mathrm{T}_{4}$ & 142.7 & 180.2 & nd & 97.5 & 44.9 & nd & 74.6 & 59.9 \\
\hline $\mathrm{T}_{7}$ & 55.2 & 102.9 & 106.4 & 44.1 & 52.0 & 84.2 & 73.2 & 36.1 \\
\hline $\mathrm{T}_{10}$ & 47.8 & 166.7 & 164.0 & 39.6 & 16.2 & 64.7 & 53.2 & 35.1 \\
\hline $\mathbf{T}_{13}$ & 21.3 & 200.6 & 172.4 & 23.9 & 18.5 & 57.7 & 60.9 & 16.4 \\
\hline $\mathbf{T}_{17}$ & 12.9 & 148.5 & 126.4 & 17.1 & 13.4 & 45.3 & 40.0 & 15.9 \\
\hline $\mathrm{T}_{21}$ & 36.6 & 232.4 & 84.3 & 37.1 & 18.0 & 66.9 & 65.7 & 23.2 \\
\hline $\mathrm{T}_{24}$ & 109.3 & 760.6 & 562.5 & 118.6 & 12.0 & 32.9 & 39.5 & 15.5 \\
\hline
\end{tabular}


Table 7. The in vitro $\beta$-carboxylase activity (PEPC+PEPCK+PYRC) of $>1 \mu \mathrm{m}$ and $<1 \mu \mathrm{m}$ fractions in the control and enriched $\mathrm{N}$ treatments.

nd: no data; data in bold denote a period of darkness

\begin{tabular}{|c|c|c|c|c|c|c|c|c|}
\hline & \multicolumn{4}{|c|}{$\begin{array}{c}>1 \mu \mathrm{m} \beta \text {-carboxylase activity } \\
\left(\mathrm{nmol} \mathrm{CO} \mathrm{CO}_{2} \mathrm{~L}^{-1} \mathrm{~h}^{-1}\right)\end{array}$} & \multicolumn{4}{|c|}{$\begin{array}{c}<1 \mu \mathrm{m} \beta \text {-carbxylase activity } \\
\left(\text { nmol CO}{ }_{2} \mathrm{~L}^{-1} \mathrm{~h}^{-1}\right)\end{array}$} \\
\hline & Control & $+\mathrm{NH}_{4}^{+}$ & $+\mathrm{NO}_{3}^{-}$ & +taurine & Control & $+\mathrm{NH}_{4}^{+}$ & $+\mathrm{NO}_{3}^{-}$ & +taurine \\
\hline $\mathrm{T}_{0}$ & 10.4 & 9.1 & 13.8 & 15.1 & 15.6 & 14.2 & 11.8 & 14.7 \\
\hline $\mathrm{T}_{2}$ & 21.1 & 17.8 & 15.4 & 17.8 & 26.4 & 12.5 & 28.8 & 16.1 \\
\hline $\mathrm{T}_{4}$ & 20.1 & 8.6 & nd & 9.5 & 11.6 & nd & 23.5 & 12.1 \\
\hline $\mathrm{T}_{7}$ & 16.9 & 14.0 & 14.9 & 7.0 & 15.1 & 15.0 & 16.8 & 12.1 \\
\hline $\mathrm{T}_{10}$ & 9.9 & 22.3 & 13.3 & 12.8 & 18.2 & 23.5 & 17.0 & 6.7 \\
\hline $\mathbf{T}_{13}$ & 19.5 & 32.0 & nd & 15.0 & 11.3 & 11.4 & 15.5 & 12.3 \\
\hline $\mathbf{T}_{17}$ & 20.3 & 23.1 & 11.8 & 11.1 & 13.2 & 8.2 & 10.9 & 25.5 \\
\hline $\mathrm{T}_{21}$ & 22.7 & 39.2 & 25.7 & 28.9 & 20.8 & 16.1 & 22.8 & 11.3 \\
\hline $\mathrm{T}_{24}$ & 11.7 & 12.0 & 26.5 & 19.0 & 5.9 & 6.1 & 7.1 & 6.5 \\
\hline
\end{tabular}


Table 8. The cellular pool of Rubisco and PEPC enzymes of $<1 \mu \mathrm{m}$ picophytoplankton in the control and $\mathrm{N}$ enriched treatments.

nd: no data; data in bold denote a period of darkness

\begin{tabular}{ccccccccc}
\hline & \multicolumn{3}{c}{$\begin{array}{c}\text { Rubisco activity per cell } \\
\left(\text { fmol CO}_{2} \text { cell }^{-1} \mathrm{~h}^{-1}\right)\end{array}$} & \multicolumn{3}{c}{$\begin{array}{c}\text { PEPC activity per cell } \\
\left(\mathrm{fmol} \mathrm{CO}_{2} \text { cell }^{-1} \mathrm{~h}^{-1}\right)\end{array}$} \\
& Control & $+\mathrm{NH}_{4}{ }^{+}$ & $+\mathrm{NO}_{3}^{-}$ & + taurine & Control & $+\mathrm{NH}_{4}^{+}$ & $+\mathrm{NO}_{3}{ }^{-}$ & + taurine \\
\hline $\mathrm{T}_{0}$ & 2.65 & 2.35 & 2.28 & 1.68 & 0.38 & 0.35 & 0.17 & 0.41 \\
$\mathrm{~T}_{2}$ & 1.59 & 2.08 & 2.35 & 2.68 & 0.20 & 0.23 & 0.52 & 0.30 \\
$\mathrm{~T}_{4}$ & 1.45 & nd & 2.67 & 2.33 & 0.27 & nd & 0.11 & 0.14 \\
$\mathrm{~T}_{7}$ & 1.71 & 2.53 & 2.34 & 1.26 & 0.50 & 0.22 & 0.37 & 0.23 \\
$\mathrm{~T}_{10}$ & 0.62 & 1.56 & 1.31 & 1.58 & 0.37 & 0.24 & 0.21 & 0.24 \\
$\mathrm{~T}_{13}$ & $\mathbf{0 . 7 2}$ & $\mathbf{1 . 2 0}$ & $\mathbf{1 . 2 6}$ & $\mathbf{0 . 7 1}$ & $\mathbf{0 . 3 2}$ & $\mathbf{0 . 1 9}$ & $\mathbf{0 . 2 8}$ & $\mathbf{0 . 1 7}$ \\
$\mathrm{T}_{17}$ & $\mathbf{0 . 6 8}$ & $\mathbf{0 . 8 8}$ & $\mathbf{0 . 9 8}$ & $\mathbf{0 . 7 3}$ & $\mathbf{0 . 3 8}$ & $\mathbf{0 . 1 1}$ & $\mathbf{0 . 2 1}$ & $\mathbf{0 . 2 7}$ \\
$\mathrm{T}_{21}$ & 0.86 & nd & 1.31 & 1.31 & 0.55 & nd & 0.11 & 0.47 \\
$\mathrm{~T}_{24}$ & 0.88 & nd & 0.86 & 0.84 & 0.20 & nd & 0.10 & 0.05 \\
\hline
\end{tabular}




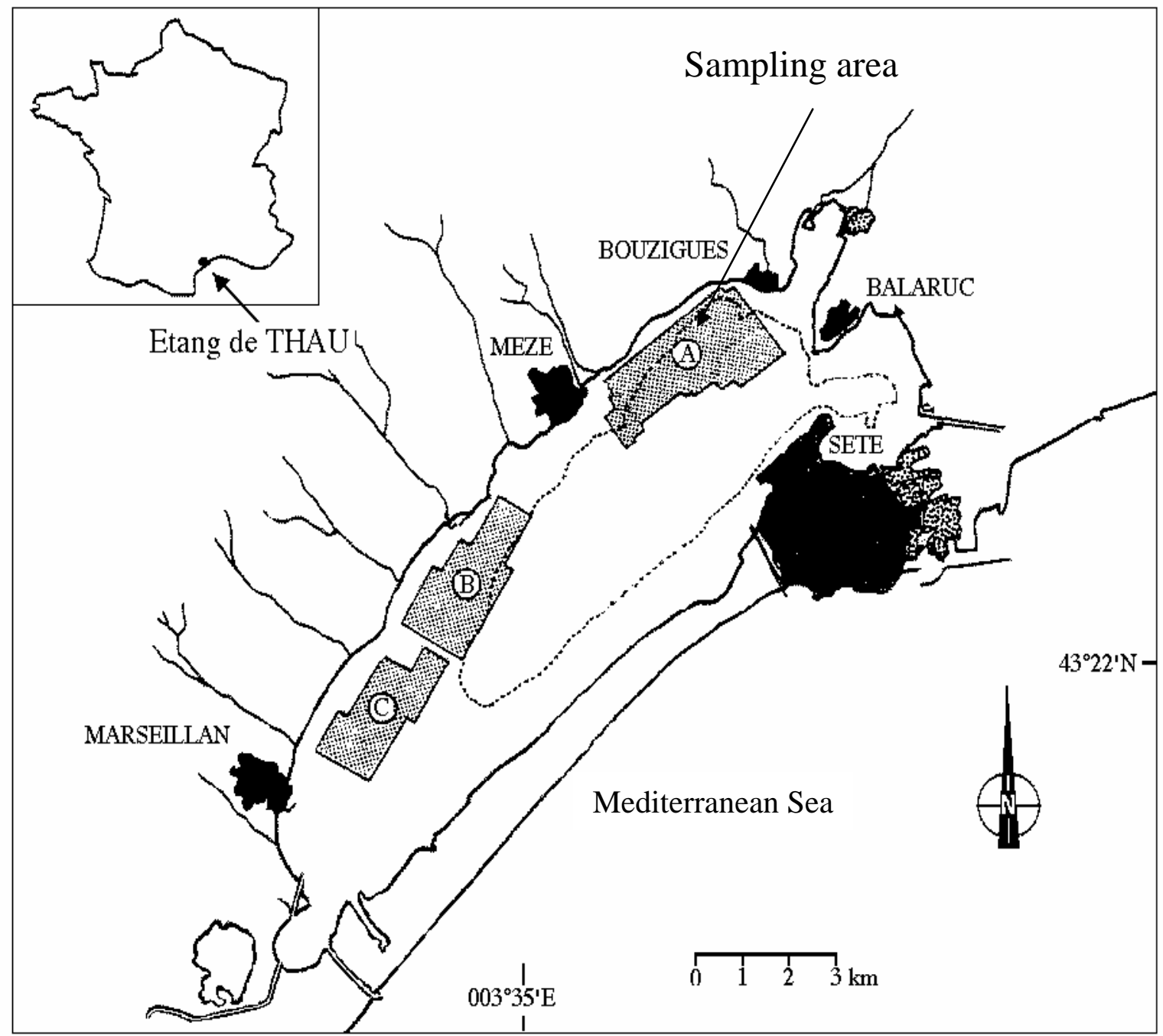

Fig 1. Map of sampling area in Thau lagoon. Grey and black areas denote the shellfish cultivation area and towns respectively. 
A) $>1 \mu$ m phytoplankton

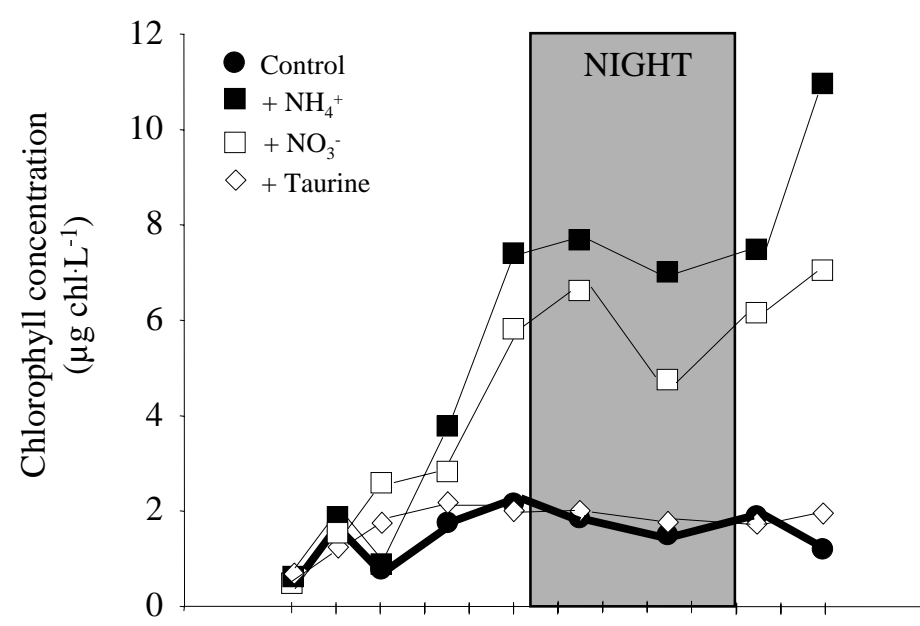

B) $<1 \mu$ phytoplankton

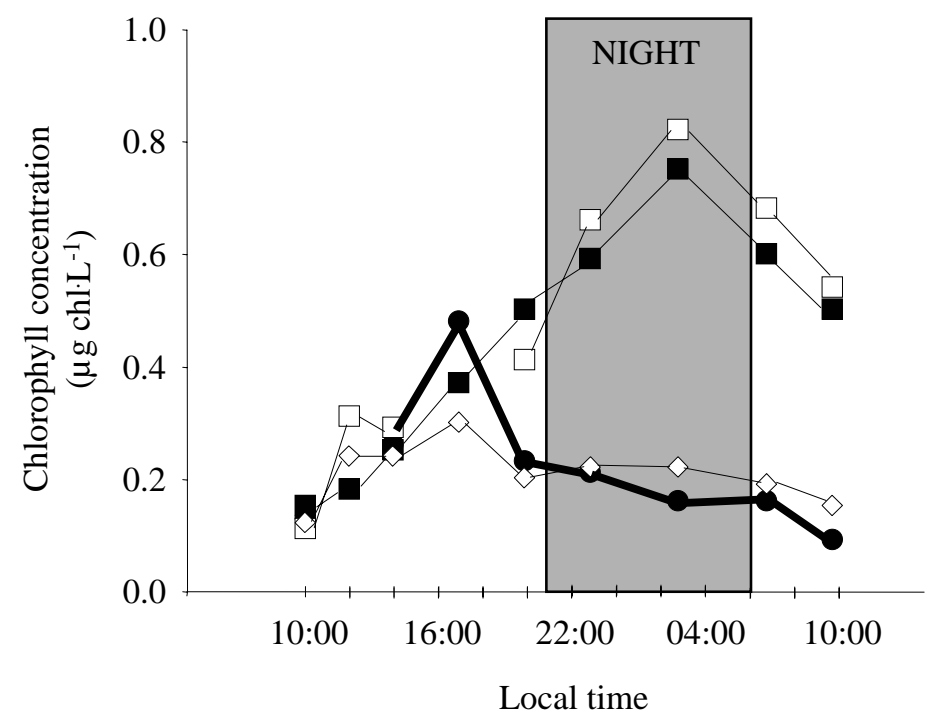

Fig 2. Chlorophyll $(\underline{a}+\underline{b}+\underline{c})$ concentrations of $(A)>1 \mu$ m phytoplankton and of $(B)<1 \mu \mathrm{m}$ phytoplankton in the control and enriched $\mathrm{N}$ treatments during the incubation experiment 
Control

+ Taurine

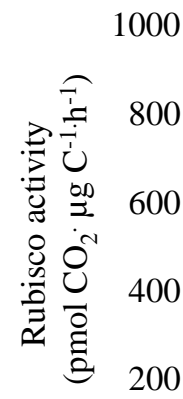

A) Without DIN enrichments

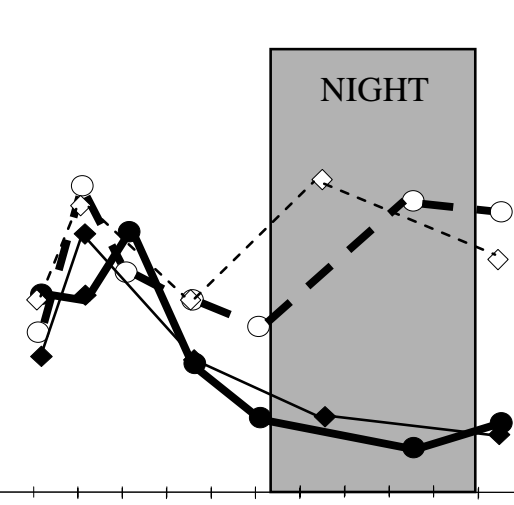

$\checkmark+$ Taurine

200

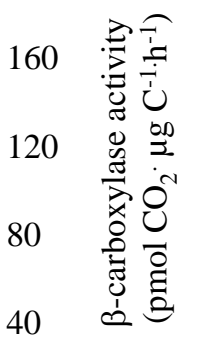

0 0

$\boldsymbol{\square}+\mathrm{NH}_{4}^{+}$
$\boldsymbol{\Delta}+\mathrm{NO}_{3}^{-}$

B) With DIN enrichments

$+\mathrm{NH}_{4}^{+}$

$\triangle+\mathrm{NO}_{3}{ }^{-}$

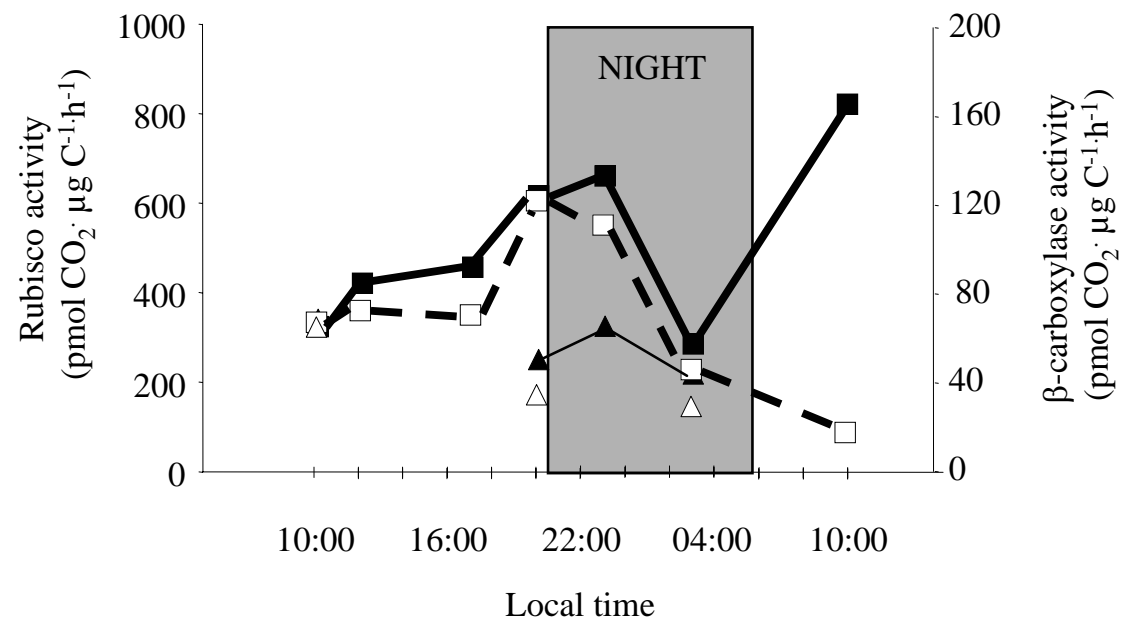

Fig 3. Total Rubisco and $\beta$-carboxylase activity expressed per particulate carbon for (A) the control and enriched taurine carboy and for (B) the ammonium and nitrate enrichments during the incubation experiment. 
A) $>1 \mu$ m phytoplankton
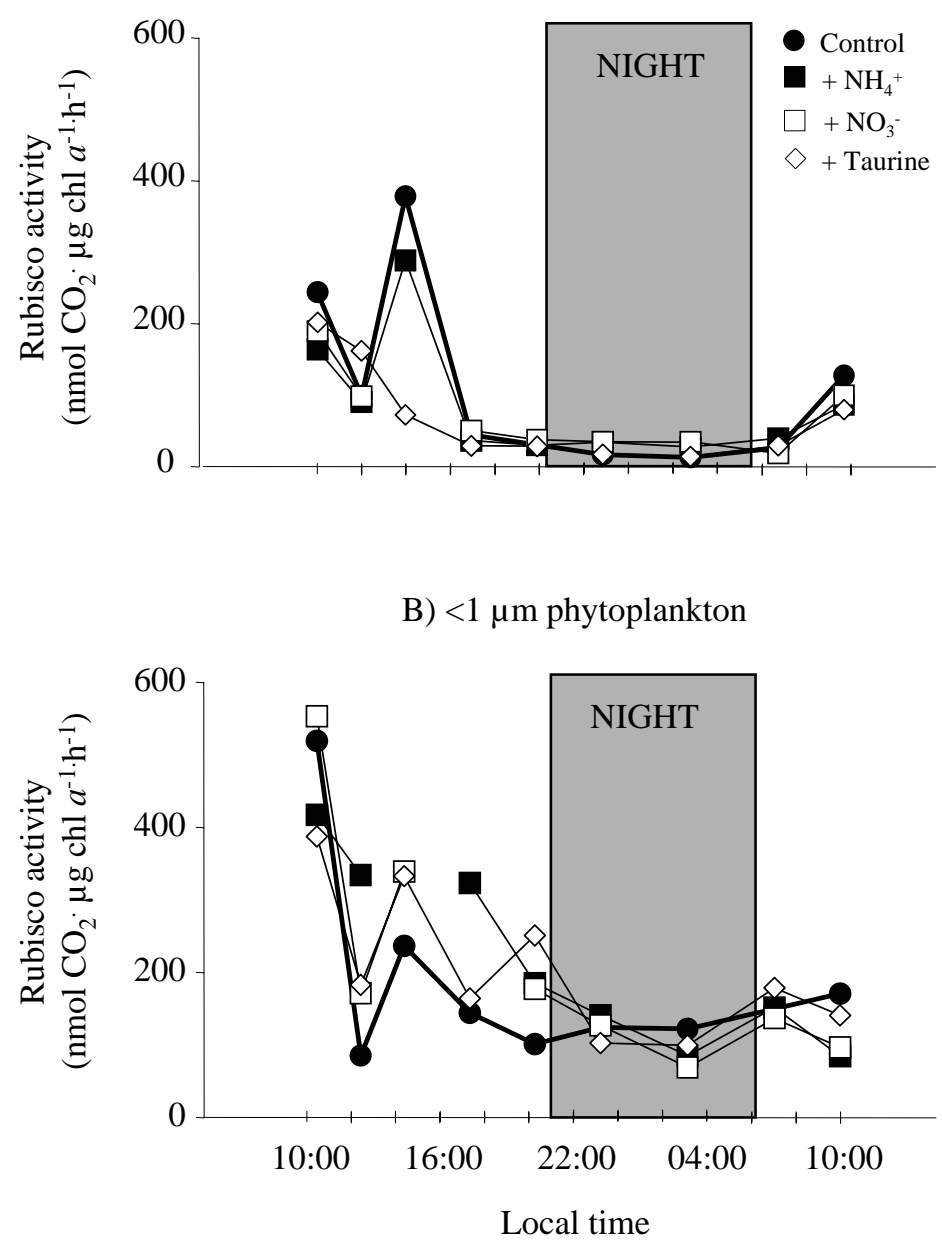

Fig 4. Rubisco activity normalised per chlorophyll $a$ concentration of (A) $>1 \mu$ m phytoplankton and of (B) $<1 \mu \mathrm{m}$ phytoplankton in the control and enriched $\mathrm{N}$ treatments during the incubation experiment. 
A) $>1 \mu$ phytoplankton

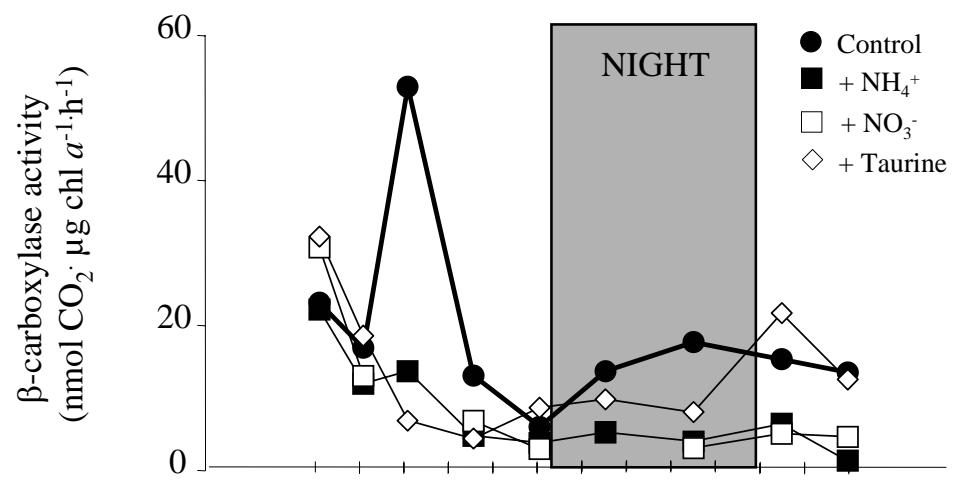

B) $<1 \mu$ m phytoplankton

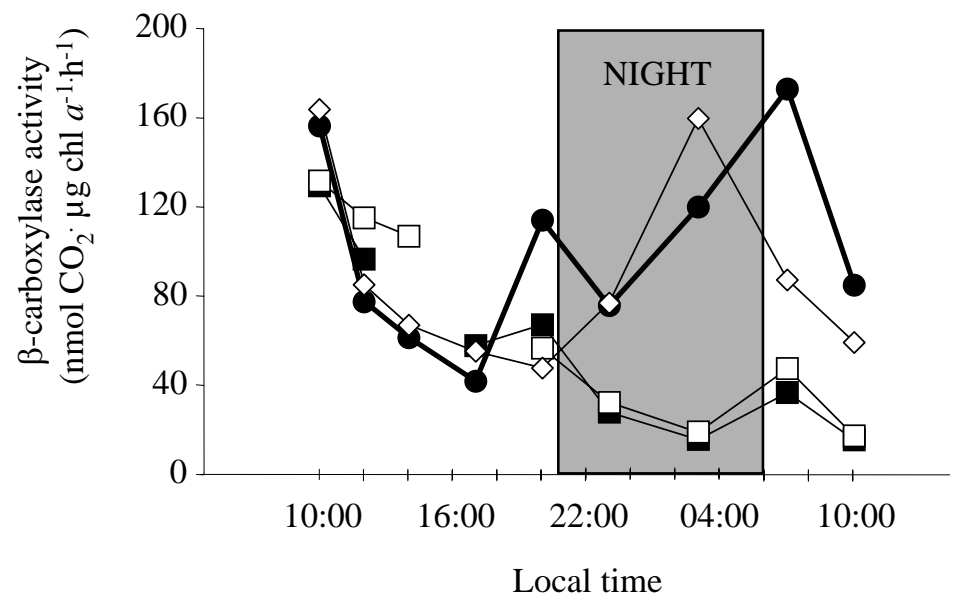

Fig 5. $\beta$-carboxylase activity normalised per chlorophyll $a$ concentrations of (A) $>1 \mu \mathrm{m}$ phytoplankton and of (B) $<1 \mu \mathrm{m}$ phytoplankton in the control and enriched $\mathrm{N}$ treatments during the incubation experiment 
A) $>1 \mu$ m phytoplankton

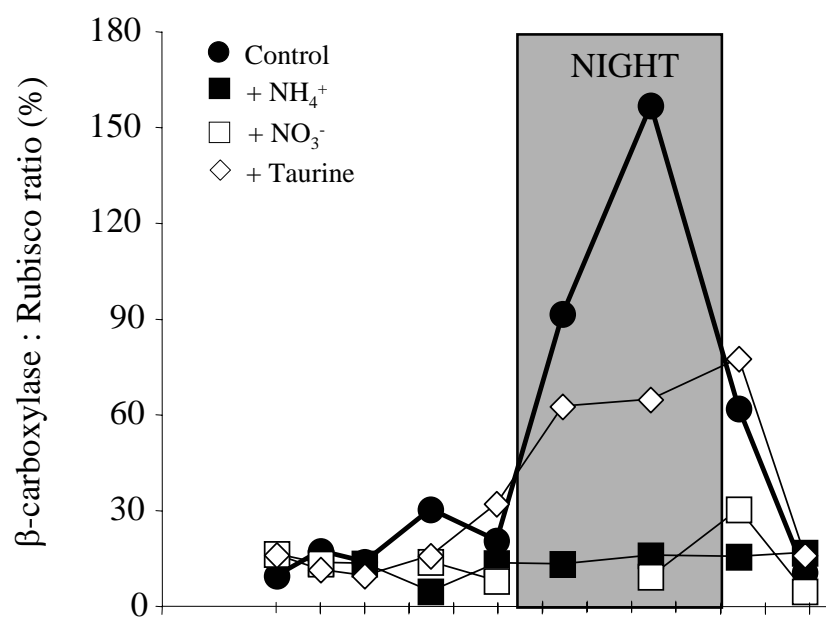

B) $<1 \mu$ m phytoplankton

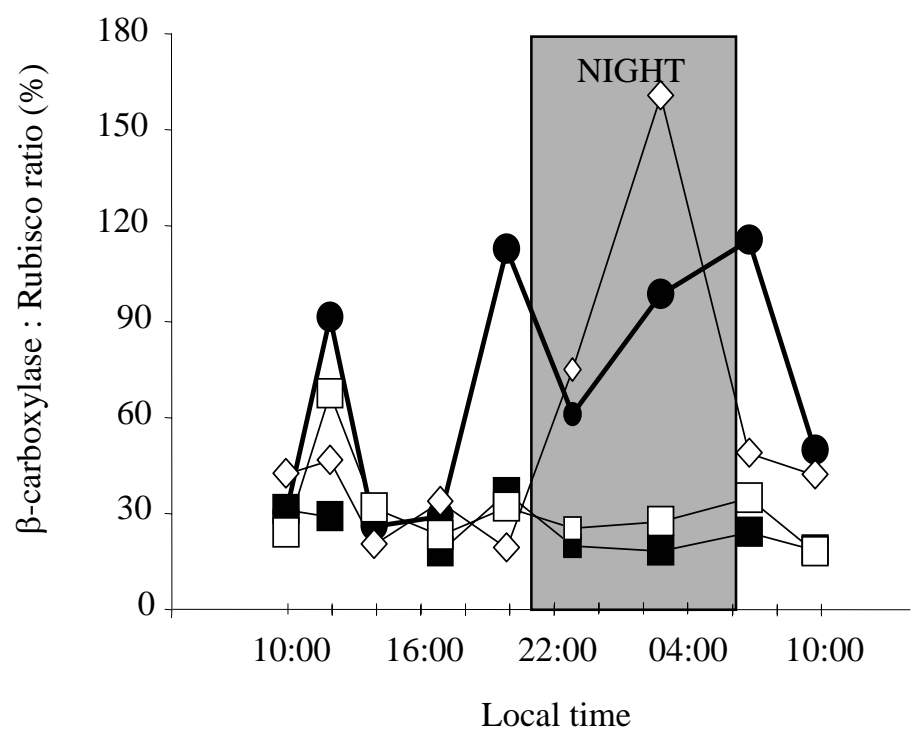

Fig 6. Ratio of $\beta$-carboxylase activity (PEPC+PEPCK+PYRC) to Rubisco activity expressed as percents measured in the control and enriched $\mathrm{N}$ treatments during the incubation experiment. 